\title{
The isoelectric point, a key to understanding a variety of biochemical problems: a minireview
}

\author{
F. M. A. H. Schuurmans Stekhoven • \\ M. H. A. G. Gorissen - G. Flik
}

Received: 8 February 2006/ Accepted: 8 June 2007/Published online: 9 August 2007

(C) Springer Science+Business Media B.V. 2007

\begin{abstract}
We address the importance of the isoelectric point (IEP) of proteins and membrane components such as phospholipids for our understanding and interpretation of isoforms and opposite charge interactions in the formation of complexes. Five examples drawn from the literature are newly approached from the IEP point of view to clarify general principles.
\end{abstract}

Keywords Isoelectric point · Isoforms ·

Protein-protein · Protein-phospholipid complexes

\section{Introduction}

The isoelectric point (IEP) of a protein is generally considered to be a mere physicochemical property that results from the summed ambivalent charge properties of its amino acid constituents. In fact, the IEP values of proteins are often not even recorded in data books, despite the primary structure of the protein being fully known. We show here that the IEP is a powerful tool to predict and understand interactions between proteins, proteins and membranes

F. M. A. H. Schuurmans Stekhoven $(\varangle)$.

M. H. A. G. Gorissen - G. Flik

Department of Animal Physiology, Faculty of Science,

Radboud University Nijmegen, Toernooiveld 1, Nijmegen

6525 ED, The Netherlands

e-mail: F.Stekhoven@science.ru.nl (phospholipids) or to determine the presence of protein isoforms.

In this paper we will address five topics/examples from our published research:

1. multi-isoelectric appearance of a glycoproteinaceous hormone, stanniocalcin;

2. charge interaction in the activation of the melanocortin-1 receptor (MC-R1) by its hormone $\alpha$-melanophore-stimulating hormone (MSH);

3 . evidence for post-translationally modified isoforms of the phospholemman in rectal glands of a shark, the spiny dogfish;

4. evaluation of the interaction between energycoupling factor B and the proton channel in the mitochondrial ATP synthase complex;

5. complexation of extranuclear histones to negative phospholipids in the plasma membrane following cell injury of fish gills.

\section{Procedures}

Calculation of the IEP

The charge of a protein is a resultant of residues that at a given $\mathrm{pH}$ become charged when they lose a proton: (1) $\mathrm{RH} \leftrightarrow \mathrm{R}^{-}+\mathrm{H}^{+} \mathrm{KDa}=\frac{\left[\mathrm{R}^{-}\right]\left[\mathrm{H}^{+}\right]}{[\mathrm{RH}]} \rightarrow$ $\left[\mathrm{R}^{-}\right]=\frac{\mathrm{KDa}[\mathrm{RH}]}{\left[\mathrm{H}^{+}\right]} \quad\left(\right.$ setting $\quad\left[\mathrm{H}^{+}\right]=x$ yields 
$\left.\left[\mathrm{R}^{-}\right]=\frac{\mathrm{KDa}[\mathrm{RH}]}{x}\right)$, and by residues that become uncharged when they lose a proton: (2) $\mathrm{R}^{\prime} \mathrm{H}^{+} \leftrightarrow$ $\mathrm{R}^{\prime}+\mathrm{H}^{+} \mathrm{KDb}=\frac{\left[\mathrm{R}^{\prime}\right]\left[\mathrm{H}^{+}\right]}{\left[\mathrm{R}^{\prime} \mathrm{H}^{+}\right]}=\frac{\left[\mathrm{R}^{\prime}\right] x}{\left[\mathrm{R}^{\prime} \mathrm{H}^{+}\right]} \rightarrow\left[\mathrm{R}^{\prime} \mathrm{H}^{+}\right]=\frac{\left[\mathrm{R}^{\prime}\right] x}{\mathrm{KDb}}$

. Further: $[\mathrm{RH}]+\left[\mathrm{R}^{-}\right]=c$ (concentration of a single residue) and $\left[\mathrm{R}^{\prime} \mathrm{H}^{+}\right]+\left[\mathrm{R}^{\prime}\right]=c$. Hence,

$$
\begin{aligned}
{\left[\mathrm{R}^{-}\right] } & =\frac{\mathrm{KDa}\left\{c-\left[\mathrm{R}^{-}\right]\right\}}{x} \rightarrow\left[\mathrm{R}^{-}\right] x \\
& =\mathrm{KDa} \cdot \mathrm{c}-\mathrm{KDa}\left[\mathrm{R}^{-}\right] \rightarrow(x+\mathrm{KDa})\left[\mathrm{R}^{-}\right] \\
& =\mathrm{KDa} \cdot \mathrm{c} \rightarrow\left[\mathrm{R}^{-}\right]=\frac{\mathrm{KDa} \cdot \mathrm{c}}{x+\mathrm{KDa}}=\frac{c}{1+\frac{x}{\mathrm{KDa}}} .
\end{aligned}
$$

Similarly:

$$
\begin{aligned}
{\left[\mathrm{R}^{\prime} \mathrm{H}^{+}\right] } & =c-\left[\mathrm{R}^{\prime}\right]=c-\frac{\left[\mathrm{R}^{\prime} \mathrm{H}^{+}\right] \cdot \mathrm{KDb}}{x} \\
& =\frac{c x-\left[\mathrm{R}^{\prime} \mathrm{H}^{+}\right] \cdot \mathrm{KDb}}{x} \rightarrow\left[\mathrm{R}^{\prime} \mathrm{H}^{+}\right] \\
& =\frac{c x}{\mathrm{Kdb}+x}=\frac{c}{1+\frac{\mathrm{KDb}}{x}}
\end{aligned}
$$

In the IEP $\left[\mathrm{R}^{-}\right]-\left[\mathrm{R}^{\prime} \mathrm{H}^{+}\right]=0$, hence $\frac{c}{{ }^{1+} \mathrm{KDa}}-\frac{c}{1+\frac{\mathrm{KDb}}{x}}=0 \rightarrow \frac{1}{{ }^{1+} \mathrm{KDa}}-\frac{1}{1+\frac{\mathrm{KDb}}{x}}=0$. Since total charge is the algebraic sum of all charged residues, one obtains for the IEP

$\sum_{1}^{i} \frac{n_{j}}{1+\frac{x}{\mathrm{KDa}_{i}}}-\sum_{1}^{j} \frac{m_{j}}{1+\frac{\mathrm{KDb}_{j}}{x}}=0$

This equation is identical to the formulation given by Sillero and Ribeiro (1989): $\sum_{i=1}^{p} \frac{1}{1+10^{\mathrm{pH}-\mathrm{pKPi}}}-\sum_{i=1}^{n} \frac{1}{1+10^{\mathrm{KKNi}-\mathrm{pH}}}=0$ with $\mathrm{pKPi}$ being equivalent to $-{ }^{10} \log \mathrm{KDb}_{\mathrm{j}}$ and $\mathrm{pKN}_{\mathrm{i}}$ equivalent to $-{ }^{10} \log \mathrm{KDa}_{\mathrm{i}}$. We use Eq. 3 and determine the IEP graphically from the intersection with the axis of zero charge difference in the $\Delta$ charge versus $\mathrm{pH}$ chart. The EMBL website gateway to IEP service (http://www.embl-heidelberg.de/cgi/pi-wrapper.pl) gives similar results with a maximal deviation of only a few percentage. On the other hand, the programme WINPEP (http://www.ipw.agrl.ethz.ch/ $\sim$ lhennig/winpep.html) gives totally different often too low - figures, and has been avoided here for the calculation of the IEP. However, this programme is reliable for the calculation of the hydropathy plot according to the procedure of Kyte and Doolittle (1982), which was applied to determine the membrane-traversing moieties of the proteins discussed.

$\mathrm{KDa}$ and $\mathrm{KDb}$ values were derived in general from the Handbook of Chemistry and Physics (Lide 1998): $2 \times 10^{-2}-4.17 \times 10^{-3}$ for $\mathrm{KDa}$ of the $\alpha$-COOH group (histidine-tryptophan), $1.94 \times 10^{-4}$ for the $\beta$-carboxyl of aspartic acid, $7.08 \times 10^{-5}$ for the $\gamma$-carboxyl of glutamic acid, $7.24 \times 10^{-9}$ for the sulfhydryl of cysteine, $7.94 \times 10^{-11}$ for the tyrosyl OH-group, $2 \times 10^{-6}$ for the phosphoryl group of phosphoserine or phosphothreonine, $1.1 \times 10^{-9}$ $3.4 \times 10^{-11}$ for the $\alpha-\mathrm{NH}_{3}^{+}$(threonine-proline), $7.94 \times 10^{-13}$ for the guanidyl group of arginine, $9.12 \times 10^{-7}$ for the imidazole group of histidine and $2.13 \times 10^{-11}$ for the $\varepsilon-\mathrm{NH}_{3}^{+}$of lysine. The KD-values for the functional groups of phosphatidylserine: $\quad(3.16-7.94) \times 10^{-4}(\mathrm{O}=\mathrm{P}-\mathrm{OH}), 3.98 \times$ $10^{-5}(-\mathrm{COOH})$, and $1.58 \times 10^{-10}\left(-\mathrm{NH}_{3}^{+}\right)$were taken from van Dijck et al. (1978). In the calculation of the IEP of phospatidylserine the term $\frac{1}{1+\mathrm{KDb} / x}$ reduces to 1 because of the negligibility of the term $\mathrm{KDb} / x$. This leads to IEP $=\frac{\mathrm{pKa} 1+\mathrm{pKa} 2}{2}$ for this particular case.

\section{Results and discussion}

Variability in IEP of trout stanniocalcin

Stanniocalcin is an anti-hypercalcemic glycoproteinaceous hormone (first detected in fish, but since found to be present in all vertebrates) that controls $\mathrm{Ca}^{2+}$ influx via the gills of fish (Flik 1990) and intestine (Sundell et al. 1992); in mammals, it promotes inorganic phosphate $(\mathrm{Pi})$ reabsorption by renal proximal tubules (Lu et al. 1994).

During in vitro synthesis of the hormone stanniocalcin by rainbow trout corpuscles of Stannius, three products of equimolar mass $(28 \mathrm{kDa}$ for the mature hormone and $32 \mathrm{kDa}$ for the prohormone monomers) were observed in a two-dimensional electrophoretic protein pattern. Stanniocalcin is homodimeric but yields monomers under the reducing conditions of the Laemmli (1970) gel electrophoresis system that have IEPs of 7, 6.1-6.3, and 5-5.2, respectively (Flik et al. 1990). Since the molecular masses of the products are for all practical purposes the same, the variation in IEP may be due to a variation in the deamidation of 
Asn-residues $(\mathrm{N})$ or a variation in the acetylation of Lys-residues $(\mathrm{K})$, a possibility not demonstrated to date. We have chosen for the former possibility in view of the fact that glycosylation of the $28-\mathrm{kDa}$ product has been shown to diminish with a decreasing IEP. Figure 1 shows that the IEP of rainbow trout stanniocalcin is negatively correlated with the number of deamidations of the N-residues, with the IEP of 6.1-6.3 corresponding to two deamidations and the IEP of 5-5.2 corresponding with six to eight deamidations. Acetylation of the K-residues would lead to similar results (not shown).

The biochemical consequence of this decreased IEP is not yet clear, but it may be a signal for metabolic clearance of the hormone that should have a short half-life to fine-tune the $\mathrm{Ca}^{2+}$ influx under variable and varying conditions. To acquire further insight, one should know the IEP of the hormone receptor as it is conceivable that when the IEP of receptor and activator approach each other, their mutual attraction will be minimised. An example of this principle will be given in the third case study presented in a following section (repulsion of phosphorylated phospholemman by the near-isoelectric Na,K-ATPase) below. This concept should be taken into consideration in future evaluations of the

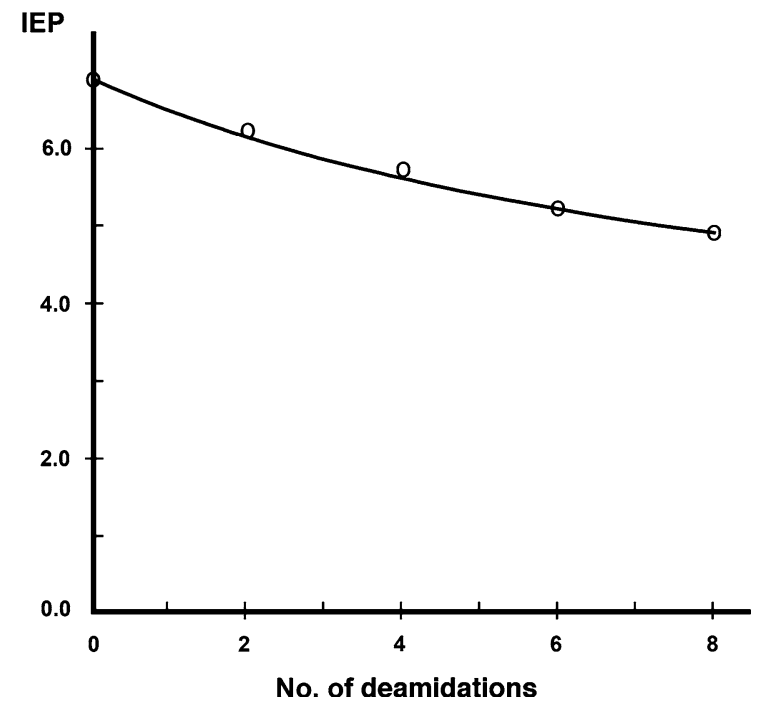

Fig. 1 The calculated isoelectric point (IEP) of the rainbow trout hormone stanniocalcin as a function of deamidation of $\mathrm{N}$ residues. The primary structure of the mature rainbow trout stanniocalcin polypeptide is derived from the SwissProt data bank under accession no. P43648 function of the stanniocalcin receptor, which awaits molecular demonstration. Only circumstantial evidence is currently available that stanniocalcin signals through a G-protein-coupled plasma membrane receptor (Flik 1990).

Hormone-receptor interactions between $\alpha$-MSH and MC-R1

Another pertinent example of charge interaction between functionally active proteins is the binding of $\alpha$-MSH to the MC-R1, which occurs through the stepwise activation of adenylate cyclase, protein kinase $\mathrm{A}$ and tyrosinase to the final formation of the skin pigment melanin (Rozaud and Hearing 2005) and its rapid dispersion in the cell in background adaptation. A revealing recent finding is that the functional difference in teleost skin pigmentation (dorsal dark, ventral light) is due to a ventral localization of the melanocortin antagonist ASP (Agouti-Signaling Protein) (Cerdá-Reverter et al. 2005). This has lead to the interesting question of whether the IEPs of agonist ( $\alpha$-MSH), antagonist (ASP) and receptor (MC-R1) have a predictive value for their interaction.

$\alpha$-MSH is the C-terminally amidated O-acetylated peptide AcSYSMEHFRWGKPV-NH $\mathrm{N}_{2}$ with a calculated IEP of 10.4. ASP (from the cyprinid Carassius auratus) comprises 125 residues (Cerdá-Reverter et al. 2005) but does not show any sequence similarity to the agonist $\alpha$-MSH. The hydropathy plot of ASP reveals an N-terminus (M1-V20) that should be able to penetrate the membrane and provide ASP with the capability for a more stable binding with the receptor than can be achieved by $\alpha-\mathrm{MSH}$. The calculated IEP of ASP is 8.71, 1.7 units lower than that of $\alpha-\mathrm{MSH}$, but still quite alkaline. The receptor MC-R1 from Danio rerio (another cyprinid) contains seven transmembrane helices and four extracellular segments (M1-Q47, N96-N123, Y187-D190, H262H281) with calculated IEPs of 6.3, 4.3, 4.9 and 10.0, respectively (Fig. 2a). One would predict that the positively charged hormone binds to one or more of the extracellular segments with an acidic IEP (segment 1,2 or 3 ). In human MC-R1, the first 28 residues can be deleted without any effect on hormone binding (Schiöth et al. 1997), providing strong evidence that the first extracellular segment 

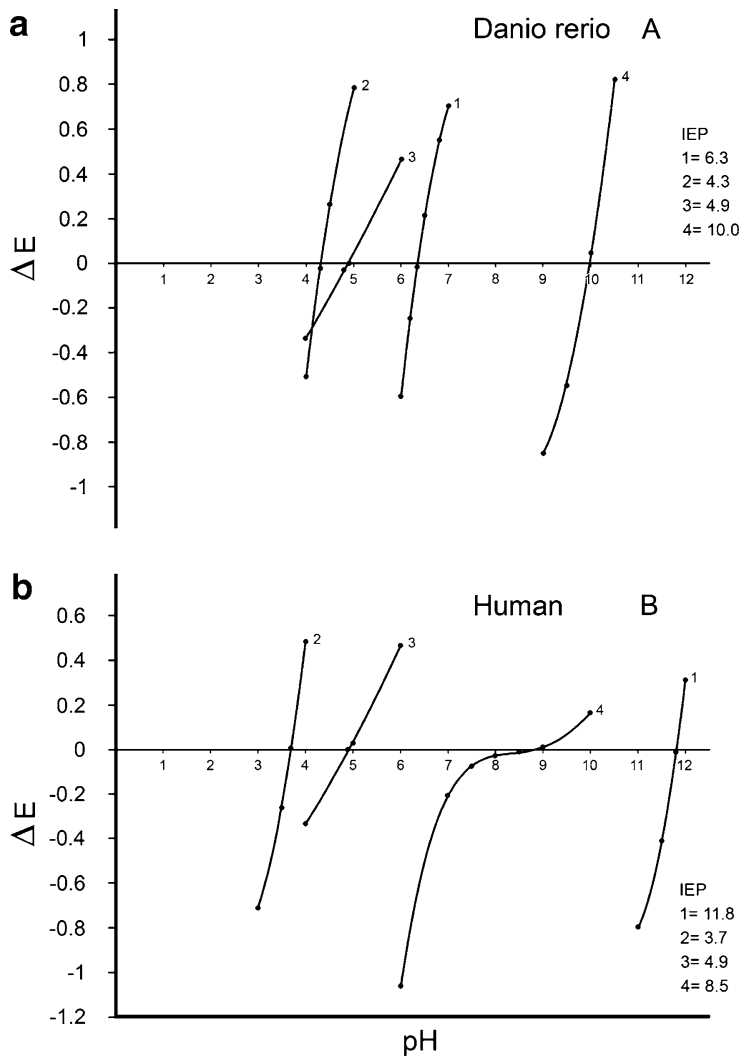

Fig. 2 Difference in charge ( $\Delta E$; Eq. 3 of Procedures) between acidic and basic amino acids as a function of $\mathrm{pH}$ in the extracellular segments of the melanocortin-1 receptor (MCR1) from Danio rerio (a) and human (b). Segments are indicated on the graphs and their IEP values in the margin to the right

is an unlikely candidate for hormone-receptor interaction. In support of this, the first extracellular segment of the human receptor has a calculated IEP of 11.8 (Fig. 2b) and will therefore repel the positively charged hormone, while it may have directing properties. The other extracellular segments have calculated IEP values that are commensurate to the counterparts in Danio rerio: 3.7 vs. 4.3 for the second segment; 4.9 vs. 4.9 for the third segment, and 8.5 vs. 10.0 for the fourth segment.

Not surprisingly, the second segment is the most promising candidate for hormone receptor interaction, and this has been confirmed by mutational studies (Frändberg et al. 1994) in which D117 (D122 in Danio rerio) was transformed to the A residue. This D residue normally complexes with $\mathrm{H} 6$ in $\alpha$-MSH (Prusis et al. 1995). A 50\% lesser reduction in the efficacy of the hormone was obtained by the mutation of $\mathrm{H} 260$ (H262 in Danio rerio) to the A residue, which is situated at the border of the fourth extracellular segment and therefore sufficiently remote from the more basic K278 residue that could have caused overall repulsion of the equally basic hormone. H260 would normally form a complex with E5 of $\alpha$-MSH, implying that the fourth extracellular segment must fold back in order to reach the E5 residue that is next to the H6 residue of the hormone. The latter consideration makes clear that not only the IEP of a whole segment is predictive for charge interaction but that certain spatial effects are also in control. Therefore, it is possible that the initial (and crucial) interaction in the second segment brings the hormone in a position for interaction with the fourth segment, rather than the reverse. This could explain why the mutation of $\mathrm{H} 260 \rightarrow$ A leads to a $50 \%$ decrease in activation compared to the mutation of D117 $\rightarrow$ A (Frändberg et al. 1994).

In ASP at least $1 \mathrm{H}$ (position 23) and $2 \mathrm{E}$ residues (E27, E28) are present in the first ten residues following the $\mathrm{N}$-terminal transmembrane fragment. These may have the binding function, analogous with the function of E5 and $\mathrm{H} 6$ in $\alpha-\mathrm{MSH}$, and thus act as competitive inhibitor (Cerdá-Reverter et al. 2005).

Shark rectal gland phospholemman isoforms

Mahmmoud et al. (2000) reported a dual spot of phospholemman $(15 \mathrm{kDa})$ in a two-dimensional gel electrophoretic separation of spiny dogfish rectal gland Na,K-ATPase. Phospholemman may be identical with the cAMP-dependent protein kinase (PKA)dependent high conductance $\mathrm{Cl}^{-}$channel in the apical membrane of this shark (Greger et al. 1985) and is dissociated from its binding to Na,K-ATPase by phosphokinase treatment (Mahmmoud et al. 2000). We determined two IEPs - 7.9 and 8.35 - from a nonlinear calibration curve of distance to the origin versus pI of their results (compare Fig. 1 of Mahmmoud et al. 2000). In a subsequent paper, Mahmmoud et al. (2003) presented the full amino acid sequence for the phospholemman, from which we calculate an IEP of 7.84 , which is not significantly different from the reported IEP of 7.9 registered for one of the two spots in the earlier study (Mahmmoud et al. 2000). In that article, however, a $\mathrm{N}$-terminal sequence was recorded that differed among the fourth $(\mathrm{E} \rightarrow \mathrm{A}), 19$ th $(\mathrm{L} \rightarrow \mathrm{K})$ 
and 24th $(\mathrm{L} \rightarrow \mathrm{K})$ residues, indicating an isoform of the $\mathrm{Cl}^{-}$-channel (Mahmmoud et al. 2003). Assuming that the sequence beyond this stretch of residues had remained unaltered in terms of acidic and basic residues, we calculate an IEP of 9.05. If, however, as the authors also suggest, K19 and K24 were erroneous, we calculate an IEP for the isoform of 8.28, which is near the second IEP of 8.35 . The $\mathrm{K}$ and $\mathrm{L}$ residues are easily misdetermined due to their partial overlap in the chromatographical separation of thiohydantoin derivatives. Peak retention time ranges (25 runs) are 17.52-17.91 min for $\mathrm{K}$ and 17.89$18.25 \mathrm{~min}$ for L. Similar isoforms with an E or D residue at the $\mathrm{N}$-terminus are found in other sharks of the Triakidae and Lamnidae families (Schuurmans Stekhoven et al. 2001). The A and E isoforms of $S$. acanthias according to our own data are in a molar ratio of 2:1. Phospholemman may not only differ in the $\mathrm{N}$-terminus, but also in its $\mathrm{C}$-terminus, as was recently demonstrated for a cytoskeleton-bound form of this protein (Kelly et al. 2004).

The reported dissociation of phospholemman from $\mathrm{Na}, \mathrm{K}-\mathrm{ATPa} e$ following phosphokinase treatment (Mahmmoud et al. 2000) can be explained by a downward shift in IEP from 7.84 for the nonphosphorylated E4 isoform to 6.2 for its twice phosphorylated form. The latter represents the maximum of phosphorylation known for the mammalian protein (Walaas et al. 1994). This IEP approaches those found for different isozymes of Na,K-ATPase, such as the $\alpha-1$ subunit (5.3; Google: AFCS protein A002647 - Signalling), the $\alpha-2$ subunit (5.5; Yamaguchi and Post 1983) and $\alpha-3$ subunit (5.0-5.3; UniProt: Q90WE7; SWALL: Q9DGL4), which leads to repulsion and dissociation of the complex (Mahmmoud et al. 2000). On the other hand, complexation of the C-terminal moiety of phospholemman to negatively charged phospholipids in the plasma membrane (Clayton et al. 2005) remains warranted (Lansbery et al. 2006) despite the phosphorylation. This mode of regulation through phosphorylation-dependent IEP changes has received only little attention to date.

Factor B's involvement in proton transport by the ATP-synthase complex

Since its discovery in 1967 (Lam et al. 1967) energy transfer factor B (FB) has been assigned a role in proton transport through the mitochondrial membrane in conjunction with the DCCD-binding protein, also known as subunit c (Sanadi et al. 1984). It has only been fairly recently that the full amino acid sequence of human factor B has been elucidated as a $20.3-\mathrm{kDa}$ protein (Belogrudov and Hatefi 2002). These data allowed us to calculate an IEP of 6.7 , which is slightly below the $\mathrm{pH}$ of the cytoplasm (6.7-7.4; Schuurmans Stekhoven 1968); the charge of the protein is therefore neutral to slightly negative. Purification of FB by means of carboxymethyl (CM)-cellulose (Lam et al. 1967) would predict a positive charge at $\mathrm{pH} 7.5$, but $\mathrm{FB}$ at this stage is still complexed to another protein of higher molecular weight and possibly higher IEP.

Full-size sequencing of the DCCD-binding protein is filed in the SwissProt database under accession \#P32876 (isoform 1: $14.2 \mathrm{kDa}$ ) and accession \#P07926 (isoform 2: $15.0 \mathrm{kDa}$ ). The IEP values for their intracellular segments are the same: 11.4. Consequently, each is capable of attracting the FB to form a complex. Yet, upon isolation of ATPsynthase, FB turns out to be absent (Walker et al. 1991; Ko et al. 2003). Given the sensitivity of FB activity to sulfhydryl (SH)-reagents (Lam 1968), it is conceivable that complex formation of FB with the DCCD binding protein occurs by means of a disulfide bridge rather than by electrostatic force. Since the oligomycin-sensitive ATPase complex (OS-ATPase) is usually isolated in the presence of SH-reagents (mercaptoethanol, Walker et al. 1991; dithiothreitol, Ko et al. 2003), it is equally conceivable that FB is being released in the procedure. In addition, the detergents used in these earlier studies may have caused dissociation as has been found, for example, in dissociating phospholemman from NaK-ATPase (Mahmmoud et al. 2000). The DCCD-binding protein contains only two C-residues (C17 and $\mathrm{C} 125$ in isoform 1; $\mathrm{C} 3$ and $\mathrm{C} 132$ in isoform 2) of which $\mathrm{C} 125$ and $\mathrm{C} 132$ are present in the second transmembrane segment of the protein channel (Fig. 3). Formation of the disulfide linkage can thus take place at $\mathrm{C} 17$ (isoform 1) or C3 (isoform 2). In contrast, FB does not traverse the membrane; however, it does contain six C-residues (C33, C71, C92, C94, C101 and C123) that could be involved in disulfide linkage while still leaving enough $\mathrm{C}$ residues free for another disulfide bridge that might function as a means of intermediary $\mathrm{H}^{+}$transport: 


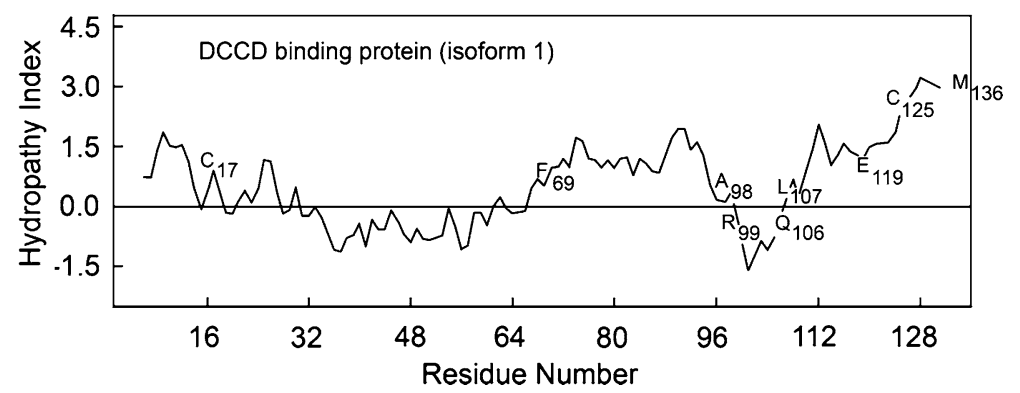

Fig. 3 Hydropathy plot of the DCCD-binding protein (isoform 1, SwissProt accession \#P32876), demonstrating the intramembranal segment (M1-K68) with its $\mathrm{C} 17$ residue, the first transmembrane (F69-A98) segment, the R99-Q106

$$
\begin{array}{ccc}
--\mathrm{S}-\mathrm{S}--+2 \mathrm{e}+2 \mathrm{H}^{+} & \leftrightarrow & 2-\mathrm{SH}-2 \mathrm{e} \\
1 . & & 2 . \\
& \leftrightarrow & --\mathrm{S}-\mathrm{S}--+2 \mathrm{H}^{+} \\
& & 3 .
\end{array}
$$

Step 1 would be the delivery of two electrons by the respiratory chain before a site of phosphorylation and step 2 would consist of the removal of two electrons immediately behind this site of phosphorylation. The final step of $\mathrm{H}^{+}$transport from the intramitochondrial space to the outside compartment and vice versa may take place via E119 (isoform 1) or E126 (isoform 2) of the DCCD-binding protein. It should be noted that the involvement of disulfide bridges in energy-linked $\mathrm{H}^{+}$transport has been suggested earlier by studies on triphenyltin inhibition of CF0-catalysed transmembrane $\mathrm{H}^{+}$transfer in chloroplasts (Gould 1978). The construction of the proton gradient takes time, and this can be reduced by addition of the SH-reagent dithiothreitol (Schuurmans Stekhoven et al. 1970).

Although the interaction between FB and the DCCD binding protein is probably not of an electrostatic character, but rather of a reversibly covalent (disulfide bridging) one, the IEP considerations have also been decisive in coming to this conclusion in this example.

The phenomenon of extranuclear histones

In a recent search for the $\mathrm{Cl}^{-}$channel phospholemman in the microsomal fraction of teleost gills, we found no phospholemman but instead histone and histone fragments in the molecular-weight region on extramembranal segment and the second (L107-M136) transmembrane segment. The latter contains the proton-transporting E119 residue and the second $\mathrm{C}$ residue of the proton channel

the gel $(13-15 \mathrm{kDa})$ that usually is occupied by phospholemman (Schuurmans Stekhoven et al. 2004). This occurrence outside of the nucleus is designated extranuclear but is generally not found in the 100,000-g sediment, but rather the 100,000- $g$ supernatant, bound to carriers like transportin, importin 5 and importin 9 (Mühlhäusser et al. 2001). These carriers exert a strong electrostatic attraction to histones; for example, transportin-SR displays an IEP of 5.29 (Kataoka et al. 1999), which is far removed from that of histone H2A (Conner et al. 1984), which has a calculated IEP of 11.3, or that of H2B (Winkfein et al. 1985), with a calculated IEP of 10.95. The same holds for the other carriers mentioned: importin 5 (SwissProt accession \#Q8BKCS) and importin 9 (SwissProt accession \#Q96P70), with calculated IEPs of 4.50 and 4.42, respectively. Only when the cytoplasmic protection of histones by their carriers is removed by activation of autolysis upon skin or gill injury (Cho et al. 2002a, b) or when nuclear import is inhibited (e.g. by lectins, Watson et al. 1995) are histones liberated into the cytoplasm where they will adhere to the cell membrane. One of the components of the cell membrane that is oriented in viable cells to the cytoplasmic face of this membrane (Verkleij et al. 1973) is phosphatidylserine. Its IEP value of 3.75-3.95 is sufficiently low to warrant binding of the positively charged histones, as was the case in our studies.

\section{Conclusion}

Our aim has been to provide support, using the examples discussed herein, to the concept that 
calculation and consideration of the IEP in protein chemical determination studies can lend weight to our understanding of a variety of phenomena. We have presented evidence demonstrating that the presence of isoforms with a different IEP can be deduced from a variation in the balance between acidic and basic amino acid residues within the polypeptide chain (phospholemman isoforms, example 3) or be due to chemical modification (deamidation) of the conserved residues (stanniocalcin isoforms, example 1). Other examples, such as the hormone-receptor interaction, reversible covalent binding and complexation of extremely opposing charges, have also been reported, which, in our opinion, provide sufficient support for the relevance of considering the IEP of the interacting proteins and their segments.

However, we cannot say that the subject of the IEP in relation to charge interactions is neglected in most publications. An example to the contrary is the elucidating explanation of the mechanism of interaction between cytochrome $\mathrm{c}$ reductase and cytochrome c oxidase with the intermediary cytochrome c (Stryer 1995). Another example is the release of phospholemman from the endoplasmic reticulum to the plasma membrane upon charge neutralization at the C-terminus by protein kinase C (PKC)-linked phosphorylation (Lansbery et al. 2006). Undoubtedly, other examples can also be found.

\section{References}

Belogrudov GI, Hatefi Y (2002) Factor B and the mitochondrial ATP synthase complex. J Biol Chem 277:60976103

Cerdá-Reverter JM, Haitina T, Schiöth HB, Peter RE (2005) Gene structure of the goldfish agouti-signalling protein: a putative role in the dorsal-ventral pigment pattern of fish. Endocrinology 146:1597-1610

Cho JH, Park IY, Kim HS, Lee WT, Kim MS, Kim SC (2002a) Cathepsin D produces antimicrobial peptide parasin I from histone $\mathrm{H} 2 \mathrm{~A}$ in the skin mucosa of fish. FASEB $\mathrm{J}$ 16:429-431

Cho JH, Park IY, Kim MS, Kim SC (2002b) Matrix metalloproteinase 2 is involved in the regulation of the antimicrobial peptide parasin I production in catfish skin mucosa. FEBS Lett 531:459-463

Clayton JC, Hughes E, Middleton DA (2005) The cytoplasmic domains of phospholamban and phospholemman associate with phospholipid membrane surfaces. Biochemistry 44:17016-17026
Connor W, States JC, Mezquita J, Dixon GH (1984) Organization and nucleotide sequence of rainbow trout histone H2A and H3 genes. J Mol Evol 20:236-250

van Dijck PWM, De Kruijff B, Verkleij AJ, van Deenen LLM, De Gier J (1978) Comparative studies on the effects of $\mathrm{pH}$ and $\mathrm{Ca}^{2+}$ on bilayers of various negatively charged phospholipids and their mixtures with phosphatidylcholine. Biochim Biophys Acta 512:84-96

Flik G (1990) Hypocalcin physiology. In: Epple A, Scanes CG, Stetson MH (eds) Progress in comparative endocrinology. Wiley-Liss, New York, pp 578-585

Flik G, Labedz T, Neelissen JAM, Hanssen RGJM, Wendelaar Bonga SE, Pang PKT (1990) Rainbow trout corpuscles of Stannius: stanniocalcin synthesis in vitro. Am J Physiol 258 (Regul Integr Comp Physiol 27):R1157-R1164

Frändberg P-A, Muceniece R, Prusis P, Wikberg J, Chhajlani V (1994) Evidence for alternate points of attachment for $\alpha$-MSH and its stereoisomer $\left[\mathrm{Nle}^{4}, \mathrm{D}-\mathrm{Phe}^{7}\right]-\alpha-\mathrm{MSH}$ at the melanocortin-1 receptor. Biochem Biophys Res Commun 202:1266-1271

Gould JM (1978) Dithiol-specific reversal of triphenyltin inhibition of $\mathrm{CF} 0$-catalyzed transmembrane proton transfer in chloroplasts. FEBS Lett 94:90-94

Greger R, Schlatter E, Gögelein $\mathrm{H}$ (1985) $\mathrm{Cl}^{-}$-channels in the apical cell membrane of the rectal gland "induced" by cAMP. Pflügers Arch 403:446-448

Kataoka N, Bachorik JL, Dreyfuss G (1999) Transportin-SR, a nuclear import receptor for SR proteins. J Cell Biol 145:1145-1152

Kelly CE, Ram ML, Francis SA, Houle TH, Cala SA (2004) Identification of a cytoskeleton-bound form of phospholemman with unique C-terminal immunoreactivity. J Membr Biol 202:127-135

Ko YH, Delannoy M, Hullihen J, Chiu W, Pedersen PL (2003) Mitochondrial ATP synthasome. Christae-enriched membranes and a multiwell detergent screening assay yield dispersed single complexes containing the ATP synthase and carriers for $\mathrm{Pi}$ and ADP/ATP. J Biol Chem 278:12305-12309

Kyte J, Doolittle RF (1982) A simple method for displaying the hydropathic character of a protein. J Mol Biol 157:105132

Lam KW (1968) Sulfhydryl group involvement in a soluble energy transfer factor of the oxidative phosphorylation system. Arch Biochem Biophys 123:642-643

Lam KW, Warshaw JB, Sanadi DR (1967) The mechanism of oxidative phosphorylation XIV. Purification and properties of a second energy-transfer factor. Arch Biochem Biophys 119:477-484

Laemmli UK (1970) Cleavage of structural proteins during the assembly of the head of bacteriophage T4. Nature 227:2612-2620

Lansbery KL, Burcea LC, Mendenhall ML, Mercer RW (2006) Cytoplasmic targeting signals mediate the delivery of phospholemman to the plasma membrane. Am J Physiol Cell Physiol 290:C1275-1286

Lide DR (1998) CRC handbook of chemistry and physics, 79th edn. CRC Press, Boca Raton, pp 7-1-7-2

Lu M, Wagner GF, Renfro JL (1994) Stanniocalcin stimulates phosphate reabsorption by flounder renal proximal tubule 
in primary culture. Am J Physiol 267(Regul Integr Comp Physiol 36):R1356-R1362

Mahmmoud YA, Cramb G, Maunsbach AB, Cutler CP, Meischke L, Cornelius F (2003) Regulation of Na,K-ATPase by PLMS, the phospholemman-like protein from shark. Molecular cloning, sequence, expression, cellular distribution, and functional effects of PLMS. J Biol Chem 278:37427-37438

Mahmmoud YA, Vorum H, Cornelius F (2000) Identification of a phospholemman-like protein from shark rectal glands. Evidence for indirect regulation of $\mathrm{Na}, \mathrm{K}-\mathrm{ATPase}$ by protein kinase $\mathrm{C}$ via a novel member of the FXYDY family. J Biol Chem 275:35969-35977

Mühlhäusser P, Müller E-C, Otto A, Kutay U (2001) Multiple pathways contribute to nuclear import of core histones. EMBO Rep 2:690-696

Prusis P, Frändberg P-A, Muceniece R, Kalvinsh I, Wikberg JES (1995) A three dimensional model for the interaction of MSH with the melanocortin-1 receptor. Biochem Biophys Res Commun 210:205-210

Rozaud F, Hearing VJ (2005) Regulatory elements of the melanocortin 1 receptor. Peptides 26:1858-1870

Sanadi DR, Pringle M, Kantham L, Hughes JB, Srivastava A (1984) Evidence for the involvement of coupling factor B in the $\mathrm{H}^{+}$channel of the mitochondrial $\mathrm{H}^{+}$-ATPase. Proc Natl Acad Sci USA 81:1371-1374

Schiöth HB, Petersson S, Muceniece R, Szardenings M, Wikberg JES (1997) Deletions of the N-terminal regions of the human melanocortin receptors. FEBS Lett 410:223-228

Schuurmans Stekhoven FMAH (1968) Energiehuishouding en metabolisme van gistmitochondriën. $\mathrm{PhD}$ thesis. BronderOffset, Rotterdam

Schuurmans Stekhoven FMAH, Sani BP, Sanadi DR (1970) Energy linked NAD reduction in phosphorylating submitochondrial particles from heavy layer beef heart mitochondria. A lag phenomenon and its localization. Biochem Biophys Res Commun 39:1026-1030

Schuurmans Stekhoven FMAH, Flik G, Wendelaar Bonga SE (2001) N-terminal sequences of small ion channels in rectal glands of sharks: a biochemical hallmark for classification and phylogeny? Biochem Biophys Res Commun 288:670-675

Schuurmans Stekhoven FMAH, Wendelaar Bonga SE, Flik G (2004) Extranuclear histones in teleost gills: an evolutionary study. Fish Physiol Biochem 30:201-211

Sillero A, Ribeiro JM (1989) Isoelectric points of proteins: theoretical determination. Anal Biochem 179:319-325

Stryer L (ed) (1995)Biochemistry, 4th edn. W.H. Freeman, New York

Sundell K, Björnsson BT, Itoh H, Kawauchi H (1992) Chum salmon (Oncorhynchus keta) stanniocalcin inhibits in vitro intestinal calcium uptake in Atlantic cod (Gadus morhua). J Comp Physiol B 162:489-495

Verkleij AJ, Zwaal RFA, Roelofsen B, Comfurius P, Kastelijn D, van Deenen LLM (1973) The asymmetric distribution of phospholipids in the human red cell membrane. A combined study using phospholipases and freeze-etch electron microscopy. Biochim Biophys Acta 323:178-193

Walaas SI, Czernik AJ, Olstad OK, Sletten K, Walaas O (1994) Protein kinase $\mathrm{C}$ and cyclic AMP-dependent protein kinase phosphorylate phospholemman, an insulin and adrenaline-regulated membrane phosphoprotein, at specific sites in the carboxy terminal domain. Biochem $\mathrm{J}$ 304:635-640

Walker JE, Lutter R, Dupuis A, Runswick MJ (1991) Identification of the subunits of F1F0-ATPase from bovine heart mitochondria. Biochemistry 30:5369-5378

Watson K, Edwards RJ, Shaunak S, Parmelee DC, Sarraf C, Gooderham NJ, Davies DS (1995) Extranuclear location of histones in activated human peripheral blood lymphocytes and cultured T-cells. Biochem Pharmacol 50:299309

Winkfein RJ, Connor W, Mezquita J, Dixon GH (1985) Histone $\mathrm{H} 4$ and $\mathrm{H} 2 \mathrm{~B}$ genes in rainbow trout (Salmo gairdnerii). J Mol Evol 22:1-19

Yamaguchi M, Post RL (1983) Isoelectric focussing of the catalytic subunit of $(\mathrm{Na}, \mathrm{K})$-ATPase from pig kidney. J Biol Chem 258:5260-5268 